\title{
Legumbres, aliados para sistemas alimentarios sostenibles
}

Naciones Unidas proclamó 2016 como el Año Internacional de las Legumbres en reconocimiento al papel fundamental que juegan en la seguridad alimentaria y nutricional, sus cualidades para la fertilidad de suelos, su contribución a la biodiversidad genética, beneficios para pequeños agricultores y capacidad de adaptación al cambio climático.

Por su parte, la FAO asumió la tarea de difundir los beneficios que tienen las legumbres como parte de sistemas alimentarios sostenibles enfocados en mejorar la alimentación y nutrición, junto con apoyar a más de 50 millones de agricultores familiares que las producen y comercializan.

Esta tarea fue exitosa y posible gracias a la especial colaboración de distintos actores públicos, organizaciones de la sociedad civil, academia, agricultores y sector privado, quienes en su conjunto, lograron difundir los aportes de las legumbres y realzar esta celebración a nivel mundial.

En las múltiples actividades realizadas en Chile seminarios, talleres, proyectos de rescate de semillas, hitos comunicacionales, actos culinarios, entre otros- las reflexiones respecto a la evolución de este cultivo han llevado a identificar grandes brechas y oportunidades a nivel nacional, que deben ser abordadas en línea con los desafíos agroalimentarios del país.

En este sentido, se destacaron las variedades locales de legumbres como un importante patrimonio genético y cultural, sus potencialidades para las zonas que sufren de sequía pues tienen características que le confieren una alta capacidad de adaptación a suelos pobres, el aporte nutricional como aliado para combatir el sobrepeso y el valor agregado del cultivo para su comercialización.

Por otra parte, se reconocieron los desafíos los cuales están principalmente enfocados en la necesidad de hacer campañas de difusión para aumentar el consumo, junto con entregar incentivos para facilitar tanto la producción como la comercialización.

De acuerdo a cifras entregadas por el Instituto Nacional de Estadística, la superficie sembrada en el país ha disminuido considerablemente. Las razones de esta disminución están relacionadas con la baja rentabilidad de estos cultivos y a la competencia que enfrentan con países como Canadá, Estados Unidos y Argentina, donde la producción es en mayor escala y con alta tecnología.
Eve Crowley

Representante en Chile de la Organización de las Naciones para la Alimentación y la Agricultura

Este trabajo fue recibido el 15 de junio de 2017. Aceptado para ser publicado: 15 de diciembre de 2015.

Por lo tanto, el consumo interno es altamente dependiente de las importaciones y del mercado externo, con precios que se mueven de acuerdo al tipo de cambio y otros factores económicos que dificultan la oferta sostenida.

En este escenario, aumentar el consumo es un desafío. Cifras nacionales dan cuenta de una disminución del consumo per cápita de las principales leguminosas a una tasa media anual de $2,7 \%$ en la última década. En promedio, los chilenos sólo comen 800 gramos de lentejas y 200 gramos de garbanzos al año, muy por debajo de lo recomendado en las guías alimentarias del Ministerio de Salud. Una explicación es el cambio 
de hábitos: sustitución de proteína vegetal por proteína animal producto de mayores ingresos, poco tiempo para dedicar a la preparación de alimentos y un estigma social que asocia este alimento a los estratos más pobres, hecho reforzado por la falta de educación e información sobre sus beneficios alimentarios y su gran potencial agrícola.

Chile cuenta con variedades locales, que tienen un alto valor culinario y que pueden entregar un sello diferenciador a la gastronomía, otorgándole una identidad territorial. Hay un potencial no sólo de rescate patrimonial sino también para combatir los altos y preocupantes niveles de sobrepeso. Debemos incorporar más legumbres en nuestras dietas, en los comedores escolares y desmitificar su consumo como un alimento pobre. Como FAO invitamos a toda la comunidad a seguir difundiendo los beneficios de las legumbres, para revindicar su papel en la seguridad alimentaria y nutricional y su contribución para alcanzar sistemas alimentarios sostenibles.

Legumes, allies for sustainable food systems

The United Nations proclaimed 2016 as the International Year of Legumes in recognition of the fundamental role they play in food and nutrition security, its qualities for soil fertility, its contribution to genetic biodiversity, benefits for small farmers and ability to adapt to change climate.

For its part, the Food and Agriculture Organization of the United Nations (FAO) took on the task of disseminating the benefits of legumes as part of a larger sustainable food system focused on improving food and nutrition, along with supporting more than 50 million family farmers who produce and market them.

This task was successful in part due to the collaboration of different public actors, civil society organizations, academia, farmers and the private sector, who as a whole, managed to disseminate the contributions of legumes and enhance their celebration worldwide.

In the many activities carried out in Chile-seminars, workshops, seed rescue projects, communication milestones, and culinary events, among others- reflections on the evolution of this crop have led to the identification of large gaps and opportunities at the national level, which should be addressed in line with the agro-food challenges of the country. In this sense, the local varieties of legumes have been highlighted for their important genetic and cultural heritage, their potential for drought-suffering areas, as they have characteristics that give them a high capacity to adapt to poor soils, the nutritional contribution as an ally to combat overweight and the added value of the crop for its commercialization.

On the other hand, challenges were identified. Challenges include the need to carry out dissemination campaigns to increase consumption, along with providing incentives to facilitate both production and marketing.

According to figures provided by the National Institute of Statistics, the area of landed planted with legumes in Chile has decreased considerably. The reasons for this decline are related to the low profitability of these crops and the competition they face with countries such as Canada and the United States, where production is on a larger scale and with high technology. Therefore, domestic consumption is highly dependent on imports and the external market, with prices that move according to the exchange rate and other economic factors that hinder sustained supply.

In this scenario, increasing consumption is a challenge. National figures show a decrease in consumption per capita of the main legumes at an average annual rate of $2.7 \%$ in the last decade. On average, Chileans eat only 800 grams of lentils and 200 grams of chickpeas per year, well below what is recommended in the food guides of the Ministry of Health. One explanation is the change in habits: substitution of vegetable protein for animal protein, which is the product of higher income, little time to dedicate to the preparation of food, and a social stigma that associates legumes with lower socioeconomic classes, a fact reinforced by the lack of education and information about food benefits and their vast agricultural potential.

Chile has local varieties of legumes, which have a high culinary value and can deliver a differentiating stamp on the local gastronomy, providing a territorial identity. There is potential not only for heritage rescue but also to combat the high and worrisome levels of overweight. We must incorporate more legumes in our diets, in school cafeterias and demystify their consumption as a poor food. The FAO invites the entire community to continue disseminating information on the benefits of legumes, to vindicate their role in food and nutrition security and their contribution to achieve sustainable food systems. 